\title{
Analisis Perkembangan Kurikulum PPKn: Dari Rentjana Pelajaran 1947 sampai dengan Merdeka Belajar 2020
}

\author{
Raharjo \\ Universitas Sebelas Maret Surakarta \\ Email: raharjoppkn@staff.uns.ac.id
}

\begin{abstract}
ABSTRAK
Di Indonesia, perkembangan kurikulum dari masa ke masa terjadi begitu dinamis. Tujuan penelitian ini ialah mengetahui bagaimana perkembangan kurikulum PPKn di Indonesia dari mulai rentjana pelajaran 1947 sampai dengan yang terbaru mengenai kurikulum merdeka belajar 2020. Metode penelitian yang digunakan yaitu library research. Adapun hasil penelitian memaparkan bahwa di Indonesia terjadi perkembangan kurikulum yang sangat dinamis dari mulai awal merdeka diawali dengan kurikulum rentjana pelajaran 1947, kurikulum rentjana pelajaran terurai 1952, kurikulum rentjana pendidikan 1964, kurikulum 1968, kurikulum 1975, kurikulum 1984, kurikulum 1994 dan suplemen kurikulum 1999, kurikulum 2004, kurikulum 2006, kurikulum 2013, dan yang terakhir sampai dengan saat ini ialah terkait dengan kurikulum merdeka belajar 2020. Bagi PPKn, secara normatif terjadi perkembangan yang cukup dinamis dalam nomenklatur, dalam perkembangan kurikulum sebelum nomenklatur yang terbaru saat ini PPKn, sebelumnya dikenal dengan berbagai nomenklatur seperti Civics, Pendidikan Kewargaan Negara, Pendidikan Moral Pancasila (PMP), Pendidikan Kewarganegaraan, dan kemudian Pendidikan Pancasila dan Kewarganegaraan (PPKn).
\end{abstract}

Kata kunci: kurikulum, PPKn, merdeka belajar

\section{PENDAHULUAN}

Pembahasan tentang dunia pendidikan menjadi topik yang akan terus eksis dan masa ke masa. Di Indonesia, isu pendidikan menjadi isu sentral dan bahkan diamanatkan oleh konstitusi untuk menjadi priotitas utama dalam anggaran belanja negara. Pendidikan itu sendiri menurut Undang-undang Nomor 20 Tahun 2003 tentang sistem pendidikan nasional ialah "usaha sadar dan terencana untuk mewujudkan suasana belajar dan proses pembelajaran agar peserta didik secara aktif mengembangkan potensi dirinya untuk memiliki kekuatan spiritual keagamaan, pengendalian diri, kepribadian, kecerdasan, akhlak mulia, serta keterampilan yang diperlukan dirinya, masyarakat, bangsa dan negara". Pengertian ini seringkali tidak dicermati dengan betul bahwa konstitusi kita mengamanatkan sebuah upaya mengembangkan "potensi” yang di dalamnya terdapat banyak hal, artinya tidak hanya perkara kognitif saja, melainkan juga mengembangkan psikomotorik dan afektif. 
Dalam rangka upaya mengembangkan potensi siswa atau peserta didik, maka dalam dunia pendidikan diperlukan kurikulum. M Asri (2017) menyatakan bahwa "Dalam dunia pendidikan terdapat beberapa komponen yang saling bersinergi agar mampu mewujudkan tujuan pendidikan itu sendiri. Semua komponen mempunyai andil yang penting, tidak terkecuali kurikulum yang mana dapat dikatakan penyangga utama dalam sebuah proses belajar mengajar. Beberapa pakar bahkan mengatakan bahwa kurikulum merupakan jantung bagi pendidikan, baik buruknya hasil pendidikan ditentukan oleh kurikulum, apakah mampu membangaun kesadaran kritis terhadap peserta didik ataukah tidak".

Pembahasan kurikulum di Indonesia ini sangatlah menarik. Hal ini dikarenakan begitu dinamisnya perubahan yang terjadi dalam perkembangan kurikulum Indonesia. Bahkan Alhamuddin memaparkan bahwa "Ada ungkapan menggelitik yang acapkali muncul seiring perubahan penguasa negeri ini yakni 'ganti menteri ganti kurikulum', nyatanya dalam perjalanan sejarah sejak kemerdekaan Indonesia tahun 1945, kurikulum pendidikan nasional memang telah berulangkali mengalami perubahan, yaitu pada tahun 1947, 1952, 1964, 1968, 1975, 1984, 1994, dan 2004, 2006 serta yang terbaru adalah kurikulum 2013". Ditambah, saat ini sudah ada pandangan baru terkait dengan kurikulum merdeka belajar.

Perubahan tersebut merupakan konsekuensi logis dari terjadinya perubahan sistem politik, sosial budaya, ekonomi, dan iptek dalam masyarakat berbangsa dan bernegara. Sebab, sistem kurikulum sebagai seperangkat rencana pendidikan memang perlu dikembangkan secara dinamis sesuai dengan tuntutan dan perubahan yang terjadi di masyarakat.

Adapun kurikulum itu sendiri, menurut Schubert (1986), memaparkan bahwa "curriculum as content or subject matter, curriculum as a program of planned activities, curriculum as intended learning outcomes, curriculum as cultural reproduction, curriculum as experience, curriculum as discrete task and concepts, curriculum as an agenda for social reconstruction". Pandangan tersebut tampaknya dipengaruhi oleh pandangan sebelumnya, seperti Stratemeyer, Forkner, dan McKim (194) yang menyatakan "Curriculum currently defined in three ways; the courses and class activities in which children and youth engage; the total range of in class and out class experiences sponsored by school; and the total life experiences of the leaner". Dengan demikian, kurikulum dapat dikatakan sebagai seperangkat rencana dan pengaturan mengenai tujuan, isi, bahan pelajaran serta cara yang digunakan sebagai pedoman 
penyelenggaraaan proses kegiatan pembelajaran untuk mencapai tujuan tertentu. Tujuan tersebut meliputi tujuan pendidikan nasional serta kesesuaian dengan kehasan, kondisi, potensi daerah, satuan pendidikan dan peserta didik.

Lebih lanjut, Alhamuddin (2014) menjelaskan bahwa "Dari perspektif historis dari masa ke masa, determinan paradigma politik dan kekuasaan yang secara bersama-sama mewarnai dan mempengaruhi secara kuat sistem pendidikan Indonesia selama ini. Corak sistem pendidikan suatu Negara pada gilirannya kembali pada stakeholder yang paling berkuasa dalam pengambilan kebijakan. Pada tataran ini, maka sistem politiklah yang berkuasa. Siapa yang berkuasa pada periode tertentu akan menggunakan kekuasaannya untuk menentukan apa dan bagaimana pendidikan diselenggarakan. Kecenderungan inilah yang kemudian turut menjadi penguat pada apa yang kemudian disitilahkan 'ganti menteri ganti kebijakan', termasuk didalamnya kurikulum pendidikan, sebab muatanmuatan politis, value, ideologi, maupun tujuan-tujuan tertentu yang diinginkan penguasa acapkali juga disetting sedemikian rupa dalam kerangka kurikulum". Seiring dengan perkembangan zaman, dengan berbagai alasan dan rasionalisasi kurikulum Indonesia terus mengalami pergantian dari periode ke periode. Keberadaan kurikulum memberi pengaruh yang signifikan bagi kualitas pendidikan yang ada di Indonesia.

Kurikulum pada prinsipnya memang menjadi hal yang vital dalam dunia pendidikan. Dikarenakan vital atau pentingnya kurikulum ini, maka para di lapangan, para pendidik harus memahami kandungan kurikulum, karena telah jelas tujuan pendidikan terdapat dalam kurikulum. Sehingga proses pendidikan dapat berlangsung dengan kondusif, interaktif, efektif dan lancar (S. Nasution, 1995: 1).

Oleh sebab itu, kurikulum menjadi hal yang terus menarik untuk dianalisis, tidak terkecuali bagi bidang kajian atau mata pelajaran PPKn (Pendidikan Pancasila dan Kewarganegaraan). Terlebih, PPKn dalam proses perjalanan dan perkembangan kurikulum seringkali mengalami dampak yang cukup signifikan, bahkan nomenklatura tau penamaan mata pelajaran ini berganti-ganti. Hal ini tidak bisa kepas dari analisis pergantian kurikulum yang bisa jadi politis, disamping perkembangan ilmu pengetahuan yang sangat dinamis, pemerintah selalu memiliki andil besar dalam proses perkembangan kurikulum ini. Oleh sebab itu, dalam ruang lingkup kajian PPKn, peneliti sangat tertarik dalam melakukan analisis perkembangan kurikulum di Indonesia, khususnya perkembangan kurikulum dalam ranah Pendidikan Pancasila dan Kewarganegaraan. 


\section{METODE PENELITIAN}

Dalam penelitian ini peneliti mengunakan metode studi pustaka (library research). Studi Pustaka ialah penelitian yang dilakukan dengan mengumpulkan berbagai macam referensi yang dapat dianggap sebagai sumber data yang akan diolah dan dianalisis (Danial A.R, 2009:80). Adapun penelitian pustaka ini memiliki tujuan untuk mengumpulkan data dan informasi dengan berbagai macam buku, majalah, dokumen, catatan dan kisahkisah sejarah serta data pendukung lainya. Pada dasarnyadata yang diperoleh melalui penelitian pustaka ini dapat dijadikan landasan dasar bagi penelitian (Zed, 2008: 3).

Penelitian ini dilakukan dengan cara menelaah dan membandingkan sumber kepustakaan untuk memperoleh data-data yang bersifat teoritis maupun praksis. Disamping itu, penelitian kepustakaan dapat mengarahkan peneliti untuk mendapatkan informasi tentang teknik-teknik penelitian yang diharapkan, sehingga peneltian yang dilakukan bukan merupakan duplikasi namun analisis kritis membandingkan berbagai macam referensi.

\section{PEMBAHASAN}

\section{Sejarah Kurikulum di Indonesia}

Dunia pendidikan Indonesia memiliki sejarah yang Panjang dalam proses perkembangan kurikulumnya.
M. Asri (2017) menulis tentang "Dinamika Kurikulum di Indonesia" yang memaparkan secara ilmiah tentang dinamika sejarah kurikulum di Indonesia. Mengenai sejarah kurikulum di Indonesia, dijelaskan bahwa "Pembicaraan tentang kurikulum tak terlepas dengan lembaga pendidikan yang mengimplementasikan kurikulum itu sendiri. Sejarah pendidikan di Indonesia sendiri sedah dimulai jauh sebelum Indonesia merdeka, yang mana dilakukan oleh Lembaga pendidikan pesantren. Kemudian setelah bangsa ini merdeka barulah Indonesia memiliki sekolahyang dikelola sendiri karena sebelum kemerdekaan sistem persekolahan dikuasai oleh para penjajah. Sebelum masuk pada pembahasan kurikulum, mari menilik sejarah pendidikan di Indonesia yang diawali dengan munculnya Pesantren, sekolah dan madrasah".

Pesantren atau pusat pendidikan islam kuat diduga berkaitan dengan kedatangan para musafir dan pedagang muslim yang masuk lewat jalur perdagangan pada abad $7 \mathrm{M}$ dan 8 M. Kemudian sejak abad $11 \mathrm{M}$ Islam sudah masuk ke pulau- pulau di nusantara dan mulai Intensif menyebar pada abad ke 13 sampai akhir abad 17 dan pada masa itu mulai berdiri pusat-pusat kekuasaan Islam sepertidi Aceh, Demak, Giri, Ternate dan Goa. Dengan demikian dapat dikatakan bahwa pesantren telah 
mulai dikenal di Indonesia (Nahrawi, 2008: 23).

Pada mulanya, "kurikulum pesantren dilandaskan pada tingkat kemudahan dan kompleksitas kitabkitab yang dipelajari, mulai dari tingkat awal, menengah dan lanjut. Kemudian dalam perkembangannya pesantren telah melakukan perubahan kurikulum dengan memasukkan pendidikan umum dalam kurikulum pesantren. Sekolah yang pertama didirikan di Jakarta pada tahun 1617 pada masa VOC yang bertujuan untuk mencetak tenaga kerja yang kompeten pada VOC" (Daulay, 2001: 35) Sistem pendidikan sekolah ini di kuasai oleh penjajah, dan baru setelah merdeka barulah Indonesia dapat mengelola sekolah sendiri. Sedangkan madrasah berkembang di jawa mulai 1912. ada model madrasah pesantren NU dalam bentuk Madrasah Awaliyah, Ibtidaiyah, Tsanawiyah, Mualimin Wustha, dan Muallimin Ulya (mulai 1919), ada madrasah yang mengaprosiasi sistem pendidikan belanda plus, seperti muhammadiyah (1912) yang mendirikan Madrasah Ibtidaiyah, Tsanawiyah, Muallimin, Mubalighin, dan Madrasah Diniyah. Ada juga model AL-Irsyad (1913) yang mendirikan Madrasah Tajhiziyah, Muallimin dan Tahassus, atau model Madrasah PUI di Jabar yang mengembangkan madrasah pertanian, itulah singkat tentang sejarah madrasah di Indonesia (M.Asri, 2017: 6-7).
Adapun sejarah pendidikan Indonesia mencatat, "pelaksanaan kurikulum dan proses pergantian terbilang relatif cepat", jika dalam pandangan khalayak awam bahwa kesan dari proses perguliran kurikulum di Indonesia adalah 'ganti Menteri pendidikan maka ganti kurikulum'. Padahal pergantian kurikulum merupakan hal biasa-biasa saja bagi negara yang mempunyai pendidikan yang maju di dunia. Hal itu dilakukan untuk "menyokong relevansi pendidikan terhadap tantangan zaman yang kian maju, sehingga kurikulum yang diterapkan di lembaga pendidikan Indonesia tidak mungkin stagnan. Pengembangan kurikulum juga didasarkan pada hasil analisis, prediksi, dan berbagai tantangan yang dihadapi baik internal maupun eksternal yang terus berubah" (Machali \& Hidayat, 2016: 421). Dengan demikian secara normatif maupun substantive, dapat disimpulkan bahwa Indonesia memiliki sejarah perkembangan kurikulum yang sangat dinamis dan cepat, bahkan dalam dinamikannya, pada saat kurikulum sedang diimplementasikan dan belum maksimal, sudah diperbarui lagi atau diganti dengan kebijakan kurikulum yang baru, oleh sebab itu dinamika perkembangan kurikulum ini perlu dibaha lebih mendalam, khususnya yaitu kurikulum PPKn, yang peneliti bahas dalam dinamika kurikukum PPKn (poin 2 pembahasan). 
2. Dinamika Kurikulum PPKn: Dari Rentjana Pelajaran 1947 sampai dengan Merdeka Belajar 2020

a. Kurikulum

\section{Pelajaran 1947}

Rentjana

Di Indonesia, kurikulum yang pertama kali lahir ialah Kurikulum 1947 atau dikenal sebagai Kurikulum Rentjana Pelajaran 1947. Dijelaskan oleh Alhamuddin (2014) bahwa "Kurikulum pertama yang lahir pada masa kemerdekaan memakai istilah dalam bahasa Belanda 'leer plan' artinya rencana pelajaran, istilah ini lebih popular disbanding istilah 'curriculum' (bahasa Inggris). Perubahan arah pendidikan lebih bersifat politis, dari orientasi pendidikan Belanda ke kepentingan nasional. Sedangkan asas pendidikan ditetapkan Pancasila. Kurikulum yang berjalan saat itu dikenal dengan sebutan 'Rentjana Pelajaran 1947', yang baru dilaksanakan pada tahun 1950. Sejumlah kalangan menyebut sejarah perkembangan kurikulum diawali dari Kurikulum 1950. Bentuknya memuat dua hal pokok: (1) daftar mata pelajaran dan jam pengajaranya; (2) garis-garis besar pengajaran".

Pada skurikulum ini, kaitannya dengan kajian bidang PPKn, dikenal istilah civics (kewarganegaraan). Istilah ini muncul di Kurikulum 1947 menggambarkan pelajaran sekolah yang menggambarkan pelajaran tata negara. Pada saat itu isinya hanya cara cara mendapatkan dan kehilangan kewarganegaraan.

\section{b. Kurikulum Rentjana Pelajaran Terurai 1952}

Setelah "Rentjana Pelajaran 1947”, pada tahun 1952 kurikulum di Indonesia mengalami penyempurnaan. Kurikulum ini lebih merinci setiap mata pelajaran yang kemudian diberi nama "Rentjana Pelajaran Terurai 1952". Kurikulum ini sudah mengarah pada suatu sistem pendidikan nasional. Yang paling menonjol dan sekaligus ciri dari kurikulum 1952 ini bahwa setiap rencana pelajaran harus memperhatikan isi pelajaran yang dihubungkan dengan kehidupan sehari-hari. Silabus mata pelajarannya menunjukkan secara jelas bahwa seorang guru mengajar satu mata pelajaran, (Djauzak Ahmad, Dirpendas periode1991-1995 dalam Alhamuddin, 2014).

Kaitannya dengan PPKn, di kurun waktu berlakunya kurikulum ini, Samsuri (2012: 2-3) memaparkan bahwa di tahun 1959/1960an ketika gegap gempita Demokrasi Terpimpin begitu kuat di panggung politik ketika itu, telah diperkenalkan mata pelajaran Civics dalam dunia pendidikan Indonesia. Hal ini ditandai dengan adanya satu buku terbitan Departemen Pendidikan, Pengajaran dan Kebudayaan (PP \& K) yang berjudul "Civics, Masyarakat dan Manusia Indonesia Baru", karangan Mr. Soepardo, dan kawan-kawan. 
Materi buku itu berisi tentang Sejarah Pergerakan Rakyat Indonesia; Pancasila; UUD 1945; Demokrasi dan Ekonomi Terpimpin, Konferensi Asia-Afrika, Hak dan Kewajiban Warga Negara, Manifesto Politik; Laksana Malaikat; dan lampiranlampiran Dekrit Presiden 5 Juli 1959, Pidato Lahirnya Pancasila, Panca Wardana, dan Declaration of Human Rights; serta pidato-pidato lainnya dari Presiden Sukarno dalam "Tujuh Bahan Pokok Indoktrinasii” (Tubapi) dan UDHR dan kebijakan Panca Wardhana dari Menteri Pendidikan, Pengajaran dan Kebudayaan Prijono. Buku Civics dan Tubapi tersebut kemudian menjadi sumber utama mata pelajaran pendidikan kewarganegaraan di sekolah-sekolah, dengan corak indoktrinatif yang sangat dominan.

\section{c. Kurikulum Pendidikan 1964}

Usai tahun 1952, menjelang tahun 1964, pemerintah kembali menyempurnakan sistem kurikulum di Indonesia. "Kali ini diberi nama Rentjana Pendidikan 1964. Pokokpokok pikiran kurikulum 1964 yang menjadi ciri dari kurikulum ini adalah bahwa pemerintah mempunyai keinginan agar rakyat mendapat pengetahuan akademik untuk pembekalan pada jenjang SD, sehingga pembelajaran dipusatkan pada program Pancawardhana" (Hamalik, 2004), yaitu pengembangan moral, kecerdasan, emosional/ artistik, keprigelan, dan jasmani. Ada yang menyebut Panca wardhana berfokus pada pengembangan daya cipta, rasa, karsa, karya, dan moral. Mata pelajaran diklasifikasikan dalam lima kelompok bidang studi: moral, kecerdasan, emosional/artistik, keprigelan (keterampilan), dan jasmaniah. Pendidikan dasar lebih menekankan pada pengetahuan dan kegiatan fungsional praktis.

\section{d. Kurikulum 1968}

Kelahiran Kurikulum 1968 bersifat politis, mengganti Rencana Pendidikan 1964 yang dicitrakan sebagai produk Orde Lama. Dari segi tujuan pendidikan, Kurikulum 1968 bertujuan bahwa pendidikan ditekankan pada upaya untuk membentuk manusia Pancasila sejati, kuat, dan sehat jasmani, mempertinggi kecerdasan dan keterampilan jasmani, moral, budi pekerti, dan keyakinan beragama. Dalam kurikulum ini tampak dilakukannya perubahan struktur kurikulum pendidikan dari Pancawardhana menjadi pembinaan jiwa pancasila, pengetahuan dasar, dan kecakapan khusus. Kurikulum 1968 merupakan perwujudan dari perubahan orientasi pada pelaksanaan UUD 1945 secara murni dan konsekuen. Kurikulum 1968 menekankan pendekatan organisasi materi pelajaran: kelompok pembinaan Pancasila, pengetahuan dasar, dan kecakapan khusus. Mata 
pelajaran dikelompokkan menjadi 9 pokok. Djauzak menyebut Kurikulum 1968 sebagai kurikulum bulat. 'Hanya memuat mata pelajaran pokok saja'. Adapun muatan materi pelajaran bersifat teoritis, tidak mengaitkan dengan permasalahan faktual di lapangan. Titik beratnya pada materi apa saja yang tepat diberikan kepada siswa di setiap jenjang pendidikan. Isi pendidikan diarahkan pada kegiatan mempertinggi kecerdasan dan keterampilan, serta mengembangkan fisik yang sehat dan kuat.

Dalam konteks bidang PPKn, perkembangan berikutnya, mata pelajaran Civics yang kemudian diganti menjadi Kewargaan Negara pada 1962, pada Kurikulum 1968 ditetapkan secara resmi menjadi "Pendidikan Kewargaan Negara". Di dalam kurikulum ini, penjabaran ideologi Pancasila sebagai pokok bahasan dianggap mengedepankan kajian tata negara dan sejarah perjuangan bangsa, sedangkan aspek moralnya belum nampak (Aman, dkk, 1982: 11). Kajian Pendidikan Kewargaan Negara untuk masingmasing jenjang berbeda-beda kekomplekannya. Untuk jenjang sekolah dasar Mata Pelajaran Pendidikan Kewargaan Negara meliputi program pembelajaran Sejarah Indonesia, Civics, dan Ilmu Bumi. Untuk jenjang SMP, Mata Pelajaran Pendidikan Kewargaan Negara meliputi program pembelajaran isinya Sejarah
Kebangsaan (30\%), Kejadian setelah Indonesia merdeka (30\%), dan UUD 1945 (40\%). Untuk jenjang SMA, Mata Pelajaran Pendidikan Kewargaan Negara meliputi program pembelajaran sebagian besar terdiri atas UUD 1945 (Somantri, 2001: 284285).

\section{e. Kurikulum 1975}

Kurikulum 19755 menekankan pada tujuan, agar pendidikan lebih efektif dan efisien. latar belakangi lahirnya kurikulum ini adalah pengaruh konsep di bidang manejemen, yaitu MBO (management by objective) yang terkenal saat itu," Metode, materi, dan tujuan pengajaran dirinci dalam Prosedur Pengembangan Sistem Instruksional (PPSI), yang dikenal dengan istilah "satuan pelajaran", yaitu rencana pelajaran setiap satuan bahasan. Setiap satuan pelajaran dirinci menjadi : tujuan instruksional umum (TIU), tujuan instruksional khusus (TIK), materi pelajaran, alat pelajaran, kegiatan belajar-mengajar, dan evaluasi. Kurikulum 1975 banyak dikritik. Guru dibuat sibuk menulis rincian apa yang akan dicapai dari setiap kegiatan pembelajaran (Surakhmad, 2009: 69).

Di dalam kurikulum ini, Samsuri (2012) menjelaskan bahwa "Penanaman nilai-nilai moral yang cenderung hegemonik dari negara melalui proses pendidikan pada era Orde Baru mulai menampakkan kekuatannya ketika secara formal 
Garis-garis Besar Haluan Negara (GBHN) Tahun 1973 menyebut perlunya: "Kurikulum di semua tingkat pendidikan berisikan Pendidikan Moral Pancasila. Meskipun sebutan "Moral Pancasila" dilekatkan untuk pendidikan kewarganegaran di jenjang pendidikan dasar dan menengah, namun materi-materi dalam masingmasing pokok bahasan, nampak bernuansa Civics seperti dalam Kurikulum 1968. Hal ini tampak dari susunan materi PMP yang dikembangkan dengan pendekatan tujuan dalam Kurikulum 1975. Sebagai gambaran penjabaran materi PMP dalam butir-butir pokok bahasan pada Kurikulum 1975 memperlihatkan bahwa materi Civics selain berupa Sejarah Kebangsaan, Kejadian setelah Indonesia merdeka, dan UUD 1945, secara eksplisit memasukan nilai-nilai dari masing-masing sila Pancasila dan pesan-pesan pentingnya pembangunan (seperti Rencana Pembangunan Lima Tahun dan GBHN) bagi bangsa Indonesia.

\section{f. Kurikulum \\ 1984, "Kurikulum 1975 yang disempurnakan".}

Kurikulum 1984 mengusung process skill approach. Meski mengutamakan pendekatan proses, tapi faktor tujuan tetap penting. Kurikulum ini juga sering disebut 'Kurikulum $1975 \quad$ yang disempurnakan'. Posisi siswa ditempatkan sebagai subjek belajar.
Dari mengamati sesuatu, mengelompokkan, mendiskusikan, hingga melaporkan. Model ini disebut Cara Belajar Siswa Aktif (CBSA) atau Student Active Leaming (SAL). Konsep CBSA yang elok secara teoritis dan bagus hasilnya di sekolahsekolah yang diujicobakan, mengalami banyak deviasi dan reduksi saat diterapkan secara nasional. Sayangnya, banyak sekolah kurang mampu menafsirkan CBSA. Yang terlihat adalah suasana gaduh di ruang kelas lantaran siswa berdiskusi, di sana-sini ada tempelan gambar, dan yang menyolok guru tak lagi mengajar model berceramah.

Dalam konteks PPKn, Sejak GBHN 1973 hingga terakhir GBHN 1998 pada era Orde Baru, bagaimana penjelasan pendidikan untuk membentuk karakter warga negara yang baik dibebankan kepada sejumlah nama mata pelajaran, di samping pendidikan kewarganegaraan dalam formulasi Pendidikan Pancasila. "Meskipun terdapat ragam derivasi dari Pendidikan Pancasila dalam namanama mata pelajaran seperti Pendidikan Moral Pancasila, Pendidikan Sejarah Perjuangan Bangsa, Pendidikan Pendahuluan Bela Negara, Pendidikan Kewarganegaraan, dan Pendidikan P4, pada akhirnya bermuara kepada model pendidikan yang bersifat topdown. Artinya kategori warga negara yang baik merupakan kategorisasi negara terhadap warga negara 
berdasarkan tafsir negara mengenai apa yang baik dan buruk sebagai warga negara, bukan sebaliknya warga negara yang menentukan kategorinya sendiri. Warga negara seolah-olah tidak berwenang membuat pengertiannya sendiri sebagai anggota dari sebuah sistem kehidupan politik bernama negara. "Dari penelusuran terhadap proses penyusunan Ketetapan MPR tentang P4 tersebut, penulis belum berhasil melacak argumentasi baik dari pemerintah maupun MPR sendiri tentang penjabaran $\mathrm{P} 4$ menjadi 36 butir nilai Pancasila. Hanya saja ada satu pandangan dari Fraksi Utusan Daerah (FUD) di MPR" (Darmodihardjo, 1980: 109-115) tentang pentingnya P4. Ada empat alasan pentingnya P4 menurut FUD, yaitu alasan filosofis, historis, yuridis-konstitusional, dan pedagogis psikologis. Dari keempat alasan tersebut, alasan pedagogis-psikologis menjadikan P4 relevan untuk dijadikan materi pembelajaran PMP di sekolah. Selama periode Orde Baru, pendidikan sebagai instrumen pembentukan karakter warga negara menampakkan wujudnya dalam standardisasi karakter warga negara. "Standardisasi itu mencerminkan civic virtues (kebajikan-kebajikan warga negara) yang disajikan dalam mata pelajaran PMP dan PPKn dengan memasukan materi pembelajaran Pancasila yang dijabarkan dari butir-butir P4. Civic virtues itu masingmasing dijabarkan dari nilai-nilai moral Pancasila menjadi 36 butir pengamalan. P4 inilah yang kemudian menjadi keharusan pedoman atau arah petunjuk tingkah laku setiap warga negara, sebagaimana disusun dalam Tabel 2. Meskipun Pasal 1 Ketetapan MPR No. II/MPR/1978 menjelaskan bahwa "Pedoman Penghayatan dan Pengamalan Pancasila tidak merupakan tafsir Pancasila sebagai Dasar Negara sebagaimana tercermin dalam Pembukaan UUD 1945, Batang Tubuh dan Penjelasannya, tetapi P4 menjadi kelihatan lebih penting dari Pancasila itu sendiri. Lebih jauh, P4 dan Pancasila menjadi kata saktill dalam segenap kesempatan pejabat dari tingkat pusat hingga local dalam forum-forum formal maupun non formal. (Samsuri, 2012: 5).

Adapun Materi P4 dalam kajian pendidikan kewarganegaraan pada mata pelajaran PMP makin dikokohkan dalam Mata Pelajaran PMP Kurikulum 1984. Uraian pokokpokok bahasan sebagai materi PMP dijabarkan menurut urutan sila-sila Pancasila, sebagaimana penjabaran P4 terhadap tafsir pengamalan Pancasila. Meskipun aspek afektif menjadi titik berat dalam PMP Kurikulum 1984, namun materi yang dibahas lebih banyak memuat aspek pengetahuan (kognitif) ketika mengkaji pokok bahasan seperti hak azasi manusia, azas dan makna keadilan, UUD 1945, lembagalembaga negara, badan peradilan, kemerdekaan Indonesia, kerjasama 
internasional, dan kajian terhadap Pancasila itu sendiri.

\section{g. Kurikulum 1994 dan Suplemen Kurikulum 1999}

Kurikulum 1994 merupakan hasil upaya untuk memadukan kurikulumkurikulum sebelumnya, terutama kurikulum 1975 dan 1984. Sayang, perpaduan antara tujuan dan proses belum berhasil. Sehingga banyak kritik berdatangan, disebabkan oleh beban belajar siswa dinilai terlalu berat, dari muatan nasional sampai muatan lokal. Materi muatan lokal disesuaikan dengan kebutuhan daerah masing-masing, misalnya Bahasa daerah kesenian, keterampilan daerah, dan lain-lain. Berbagai kepentingan kelompokkelompok masyarakat juga mendesak agar isuisu tertentu masuk dalam kurikulum. Akhirnya, Kurikulum 1994 menjelma menjadi kurikulum super padat. Kejatuhan rezim Soeharto pada 1998, diikuti kehadiran Suplemen Kurikulum 1999. Tapi perubahannya lebih pada menambal sejumlah materi pelajaran saja.

Kaitannya dengan PPKn, Pada tahun 1994, nama Pendidikan Moral Pancasila diganti dengan Pendidikan Pancasila dan Kewarganegaraan (PPKn). Bila dikaitkan dengan kurikulum sebelumnya, mata pelajaran tersebut memadukan konsep Pendidikan Moral Pancasila (PMP) dengan Pendidikan Kewargaan Negara (PKN). Istilah Pendidikan Moral Pancasila diperbaiki menjadi Pendidikan Pancasila dan Kewarganegaraan dan Pendidikan Kewargaan Negara diubah menjadi Pendidikan Kewarganegaran. Kemudian dipadukan menjadi Pendidikan Pancasila dan Kewarganegaraan". Pendidikan Pancasila memiliki konotasi lebih luas dan utuh daripada "Pendidikan Moral Pancasila, karena Pancasila tidak hanya memiliki dimensi moral, tetapi juga mengandung konsep, nilai, moral, dan norma. Karena itu, perubahan ini sangat tepat. Materi yang terkandung dalam pelajaran PPKn tidak jauh berbeda dengan materi yang terkandung dalam pelajaran PMP". Selanjutnya pada tahun 1999 dimasukkan suplemen (tambahan) materi PPKn sesuai dengan perubahan kehidupan ketatanegaraan setelah era reformasi. Materi P-4 secara resmi tidak lagi dipakai dalam suplemen kurikulum 1999, karena Tap MPR tentang P-4 telah dicabut dengan Tap MPR No. XVIII/MPR/1998. Suasana kajian moral Pancasila yang tidak lain merupakan bentuk penataran secara terbatas\| materi P4 untuk jenjang pendidikan formal, makin diperjelas dengan kehadiran Mata Pelajaran PPKn Kurikulum 1994. Dalam Kurikulum 1994 dijelaskan pengertian PPKn sebagai berikut: "PPKn adalah wahana untuk mengembangkan dan melestarikan nilai luhur dan moral yang berakar pada budaya bangsa Indonesia yang 
diharapkan dapat diwujudkan dalam kehidupan sehari-hari siswa, baik sebagai individu maupun sebagai anggota masyarakat, warga negara dan makhluk ciptaan Tuhan Yang Maha Esa" (Kepmendikbud No. 060/U/1993 tanggal 25 Februari 1993 Kurikulum Pendidikan Dasar, GBPP SD Mata Pelajaran PPKn).

Terkait pengertian tersebut, Samsuri (2012) memaparkan bahwa "Sudah dipastikan bahwa nilai luhur dan moral yang berakar pada budaya bangsa Indonesiall ialah nilai-nilai moral Pancasila. Persoalannya, nilai moral Pancasila yang mana? Dengan memperhatikan konteks politik ketika itu tentu saja nilai moral Pancasila tersebut adalah butir-butir nilai moral yang dimuat dalam P4. Butir-butir nilai moral Pancasila terutama dalam mata pelajaran PPKn Kurikulum 1994 menggambarkan bagaimana program pendidikan $\mathrm{P} 4$ melalui jalur sekolah menemukan basis legitimasinya. Materi PPKn dominan nilai-nilai moral yang dijabarkan dari 36 butir nilai moral Pancasila dalam P4. Penyusunan uraian materi PPKn sangat sarat dengan muatan tafsir rezim politik tentang Pancasila. Keterlibatan BP7 dan Lembaga Ketahanan Nasional dalam penyusunan nilai-nilai moral Pancasila yang harus dimuat dalam Kurikulum PPKn menunjukkan betapa pendidikan kewarganegaraan dalam wujud PPKn memiliki arti strategis dalam pembentukan karakter warga negara yang Pancasilais.
Walaupun kelihatannya baik, dalam pergumulan logika penetapan namall dari nama nilai-nilai tersebut cenderung seperti bermain-main dengan angka-angka berapa banyak butir nilai itu harus disusun".

Profil PPKn dalam Kurikulum 1994 sebagai perluasan kajian P4 di sekolah dapat dicermati dari ruang lingkup materinya mulai dari SD hingga SMA yang mencakup nilai, moral dan norma serta nilai-nilai spiritual bangsa Indonesia dan perilaku yang diharapkan terwujud dalam kehidupan bermasyarakat, berbangsa dan bernegara sebagaimana dimaksud dalam Pedoman Penghayatan dan Pengamalan Pancasilall (Kepmendikbud No. 060/U/1993 dan Kepmendikbud No. 061/U/1993 tanggal 25 Februari 1993).

\section{h. Kurikulum 2004, "KBK (Kurikulum Berbasis Kompetensi)"}

Sebagai pengganti kurikulum 1994 adalah kurikulum 2004, yang disebut dengan Kurikulum Berbasis Kompetensi (KBK). Sanjaya (2005) menjelaskan bahwa "Suatu program pendidikan berbasis kompetensi harus mengandung tiga unsur pokok, yaitu: pemilihan kompetensi yang sesuai; spesifikasi indikator-indikator evaluasi untuk menentukan keberhasilan pencapaian kompetensi; dan pengembangan pembelajaran. KBK memiliki ciri-ciri sebagai berikut: Menekankan pada 
ketercapaian kompetensi siswa baik secara individual maupun klasikal, berorientasi pada hasil belajar (learning outcomes) dan keberagaman. Kegiatan pembelajaran menggunakan pendekatan dan metode yang bervariasi, sumber belajar bukan hanya guru, tetapi juga sumber belajar lainnya yang memenuhi unsur edukatif. Penilaian menekankan pada proses dan hasil belajar dalam upaya penguasaan atau pencapaian suatu kompetensi”. Struktur kompetensi dasar KBK ini dirinci dalam komponen aspek, kelas dan semester. Keterampilan dan pengetahuan dalam setiap mata pelajaran, disusun dan dibagi menurut aspek dari mata pelajaran tersebut. Pernyataan hasil belajar ditetapkan untuk setiap aspek rumpun pelajaran pada setiap level. Perumusan hasil belajar adalah untuk menjawab pertanyaan, "Apa yang harus siswa ketahui dan mampu lakukan sebagai hasil belajar mereka pada level ini?". Hasil belajar mencerminkan keluasan, kedalaman, dan juga kompleksitas kurikulum dinyatakan dengan kata kerja yang dapat diukur dengan berbagai teknik penilaian. Setiap hasil belajar memiliki seperangkat indikator. Perumusan indikator adalah untuk menjawab pertanyaan, "Bagaimana kita mengetahui bahwa siswa telah mencapai hasil belajar yang diharapkan?"

Adapun pada tahun 2004 kurikulum PKn SD diintegrasikan dengan mata pelajaran IPS, menjadi PKPS (Pendidikan Kewarganegaraan dan Pengetahuan Sosial), sementara di tingkat SMP dan SMA merupakan mata pelajaran yang berdiri sendiri. Kurikulum Berbasis Kompetensi kewarganegaraan tampak telah mengarah pada tiga komponen PKn yang bermutu seperti yang diajukan oleh Centre for Civic Education pada tahun 1999 dalam National Standard for Civics and Government. Ketiga komponen tersebut yaitu civic knowledge (pengetahuan kewarganegaraan), civic skills (keterampilan kewarganegaraan), dan civic disposition (karakter kewarganegaraan).

\section{i. Kurikulum 2006, "KTSP (Kurikulum Tingkat Satuan Pendidikan)"}

Pelaksanaan KBK masih dalam uji terbatas, namun pada awal tahun 2006, uji terbatas tersebut dihentikan. Dan selanjutnya dengan terbitnya permen nomor 24 tahun 2006 yang mengatur pelaksanaan permen nomor 22 tahun 2006 tentang standar isi kurikulum dan permen nomor 23 tahun 2006 tentang standar kelulusan, lahirlah kurikulum 2006 yang pada dasarnya sama dengan kurikulum 2004. Perbedaan yang menonjol terletak pada kewenangan dalam penyusunannya, yaitu mengacu pada jiwa dari desentralisasi sistem pendidikan. "Pada kurikulum 2006, pemerintah pusat menetapkan standar kompetensi dan kompetensi dasar, 
sedangkan sekolah dalam hal ini guru dituntut untuk mampu mengembangkan dalam bentuk silabus dan penilaiannya sesuai dengan kondisi sekolah dan daerahnya. Hasil pengembangan dari semua mata pelajaran, dihimpun menjadi sebuah perangkat yang dinamakan Kurikulum Tingkat Satuan Pendidikan (KTSP)" (Alhamuddin, 2014). Adapun penyusunan KTSP menjadi tanggung jawab sekolah di bawah binaan dan pemantauan dinas pendidikan daerah dan wilayah setempat.

Dalam konteks PPKn, di tahun 2006, perubahan kurikulum dari KBK menjadi Kurikulum Tingkat Satuan Pendidikan (KTSP). Dalam kurikulum ini PKn di sekolah dasar tidak lagi terintegrasi dengan mata pelajaran IPS, melainkan berdiri sendiri menjadi mata pelajaran PKn. Demikian pula pada tingkat SMP dan SMA PKn menjadi mata pelajaran yang berdiri sendiri.

Pada kurikulum tahun 2006 ini mata pelajaran Pendidikan Kewarganegaraan (PKn) memiliki tujuan agar peserta didik memiliki kemampuan; (1) berpikir kritis, rasional dan kreatif dalam menanggapi isu kewarganegaraan, (2) berpartisipasi secara aktif dan bertanggungjawab, bertindak secara cerdas dalam kegiatan bermasyarakat, berbangsa, dan bernegara, serta anti korupsi, (3) berkembang secara positif dan demokratis untuk membentuk diri berdasarkan karakterkarakter masyarakat Indonesia agar dapat hidup bersamasama dengan bangsa lain, (4) Berinteraksi dengan bangsa-bangsa lain dalam percaturan dunia secara langsung atau tidak langsung dengan memanfaatkan teknologi informasi dan komunikasi (Budimansyah, 2010, pp. 121-122).

\section{j. Kurikulum 2013 dan 2013 Revisi}

Pemerintah melakukan pemetaan kurikulum berbasis kompetensi yang pernah diujicobakan pada tahun 2004 (curriculum based competency). Kompetensi dijadikan acuan dan pedoman bagi pelaksanaan pendidikan untuk mengembangkan berbagai ranah pendidikan; pengetahuan, keterampilan, dan sikap dalam seluruh jenjang dan jalur pendidikan, khususnya pada jalur pendidikan sekolah.

Kurikulum 2013 berbasis kompetensi memfokuskan pada pemerolehan kompetensi-kompetensi tertentu oleh peserta didik. Oleh karena itu, kurikulum ini mencakup sejumlah kompetensi dan seperangkat tujuan pembelajaran yang dinyatakan sedemikian rupa, sehingga pencapaianya dapat diamati dalam bentuk perilaku atau keterampilan peserta didik sebagai suatu kriteria keberhasilan. Kegiatan pembelajaran perlu diarahkan untuk membantu peserta didik menguasai sekurangkurangnya tingkkat kompetensi 
minimal, agar mereka dapat mencapai tujuan-tujuan yang telah ditetapkan. Sesuai dengan konsep belajar tuntas dan pengembangan bakat. Setiap peserta didik harus diberi kesempatan untuk mencapai tujuan sesuai dengan kemamapuan dan kecepatan belajar masing-masing (Mulyasa, 2013: 68).

Tema utama kurikulum 2013 adalah menghasilkan insan Indonesia yang produktif, kreatif, inovatif, afektif, melalui pengamatan sikap, keterampilan, dan pengetahuan yang terintegrasi. Untuk mewujudkan hal tersebut, dalam implementasi kurikulum, guru dituntut secara profesional merancang pembelajaran secara efektif dan bermakna, mengorganisir pembelajaran, memilih pendekatan pembelajaran yang tepat, menentukan prosedur pembelajaran dan pembentukan kompetensi secara efektif, serta menetapkan kriteria keberhasilan (Kementerian Pendidikan dan Kebudayaan, 2013).

Adapun pada kurikulum 2013 ini, Secara yuridis formal Kurikulum 2013 berpijak pada Undang-Undang Sistem Pendidikan Nasional Nomor 20 Tahun 2003, namun dalam pelaksanaannya didasarkan pada Peraturan Pemerintah Nomor 32 Tahun 2013 tentang Perubahan atas Peraturan Pemerintah Nomor 19 Tahun 2005 tentang Standar Nasional Pendidikan. Perubahan kurikulum tersebut berdampak pula terhadap mata pelajaran Pendidikan
Kewarganegaraan di Indonesia, yang semula menggunakan istilah Pendidikan Kewarganegaraan atau yang lebih dikenal dengan sebutan PKn berubah kembali menjadi Pendidikan Pancasila dan Kewarganegaraan atau yang lebih dikenal dengan sebutan PPKn.

Berdasarkan hasil penelitian yang dilakukan oleh Setiawati (2016, p. 70) bahwa perubahan nomenklatur didasarkan pada sejumlah masukan penyempurnaan pembelajaran $\mathrm{PKn}$ menjadi PPKn yang mengemuka dalam lima tahun terakhir, antara lain: (1) secara substansial, PKn terasa lebih dominan bermuatan ketatanegaraan sehingga muatan nilai dan moral Pancasila kurang mendapat penekanan yang proporsional; (2) secara metodologi, ada kecenderungan pembelajaran yang mengutamakan pengembangan ranah sikap (afektif), ranah pengetahuan (kognitif), sedangkan ranah keterampilan (psikomotorik) belum dikembangkan secara optimal dan utuh (koheren). Dengan ruang lingkup materi pembahasan mengenai Pancasila, sebagai dasar negara, ideologi, dan pandangan hidup bangsa, UUD 1945 sebagai hukum dasar tertulis yang menjadi landasan konstitusional kehidupan bermasyarakat, berbangsa, dan bernegara, Negara Kesatuan Republik Indonesia, sebagai kesepakatan final bentuk Negara Republik Indonesia, Bhinneka Tunggal Ika, sebagai wujud filosofi kesatuan di balik 
keberagaman

kehidupan

bermasyarakat, berbangsa, dan bernegara (Santoso, dkk., 2015). Adaapun pada K13 revisi, terkait dengan substansi PPKn tidak begitu signifikan perubahannya.

\section{k. Kurikulum 2020 "Merdeka Belajar"}

Pada prinsipnya, terkait dengan Kurikulum Merdeka Belajar 2020 ini, didasari oleh Permendikbud No. 3 Tahun 2020 Tentang SN-Dikti. Mendikbud di Era ini (Nadiem Makariem) menjadi tokoh penggagas terkait dengan wacana merdeka belajar, utamanya di Perguruan Tinggi. Menurut Nadiem, Kemendikbud menyiapkan strategi yang tidak akan keluar dari esensi pendidikan, yakni kualitas guru. Guru tidak akan mungkin bisa digantikan teknologi. Teknologi adalah alat bantu guru meningkatkan potensi mereka dan mencari guru-guru penggerak terbaik serta memastikan mereka bisa menjadi pemimpinpemimpin pembelajaran dalam sekolah-sekolah di seluruh Indonesi.

Dikutip dari laman kemendikbud.go.id, Mendikbud Nadiem Makarim menjelaskan setidaknya tiga poin utama dalam gagasan merdeka belajar, yaitu tekonologi untuk akselerasi, keberagaman sebagai esensi, dan profil pelajar Pancasila. Tentu saja, poin pertama terkait dengan perkembangan teknomogi, informasi, dan komunikasi. Namun ada hal yang sangat menarik yaitu di poin 2 dan 3 , utamanya terkait dengan PPKn, bahwa adanya penguatan keberagaman sebagai esensi, berupa "keberagaman minat dan kemampuan yang dimiliki siswa menjadi alasan paling kuat agar pengukuran kinerja siswa tidak boleh dinilai hanya menggunakan angka-angka pencapaian akademik, tetapi juga berbagai macam aktivitas lain atau ekstrakurikuler". Kearifan lokal juga merupakan unsur penting dalam pembelajaran. Setiap siswa akan lebih memahami materi bila menggunakan konteks lokal. "Setiap murid akan melihat semua mata pelajaran dan semua materi dalam konteks". Kemudian terkait dengan profil pelajar Pancasila, Dalam kesempatan yang sama, Mendikbud Nadiem menjelaskan salah satu mandat yang diberikan Presiden adalah penyesuaian kurikulum yang bertujuan mewujudkan profil para pelajar di Indonesia. Kemendikbud telah menetapkan enam indikator sebagai profil pelajar Pancasila. Adapun enam profil tersebut adalah pertama, bernalar kritis agar bisa memecahkan masalah. Hal ini berhubungan dengan kemampuan kognitif. Kedua, kemandirian, yaitu siswa secara independen termotivasi meningkatkan kemampuannya, bisa mencari pengetahuan serta termotivasi. Ketiga, adalah kreatif, di mana siswa bisa menciptakan hal baru, berinovasi secara mandiri, dan 
mempunyai rasa cinta terhadap kesenian dan budaya.

Keempat, gotong-royong, di mana siswa mempunyai kemampuan berkolaborasi yang merupakan softskill utama yang terpenting di masa depan agar bisa bekerja secara tim. Kelima, kebinekaan global yang merupakan upaya agar siswa mencintai keberagaman budaya, agama dan ras di negaranya serta dunia, sekaligus menegaskan mereka juga warga global. Keenam, berakhlak mulia. Di sinilah moralitas, spiritualitas, dan etika berada. "Sudah pasti pendidikan karakter akan menjadi salah satu pilar inti," tegas Mendikbud. Project based learning menjadi salah satu metode melatih jiwa gotong royong dan kreativitas siswa. "Bukan hanya dengan membaca materi lalu diuji, melainkan juga untuk menciptakan karya. Oleh karena itu saya mempunyai motto, kalau kita ingin melakukan transformasi pembelajaran di dalam suatu ruang kelas maka harus banyak tanya, banyak coba, banyak karya" (https://www.kemdikbud.go.id/main/ blog/2020/05/reformasi-pendidikannasional-melalui-merdeka-belajar)

\section{SIMPULAN DAN SARAN}

\section{A. Simpulan}

Perkembangan kurikulum PPKn terjadi sangat dinamis, dalam hal secara normative nomenklatur maupun sibstansi, PPKn mengalami proses perkembangan cukup panjang. Dimulai dari ertama muncul tahun 1957 dengan nama civics (kewarganegaraan) Tahun 1959 di introdusir pelajaran civics dengan "Civics Manusia Indonesia Baru" dan "Tujuh Bahan Pokok Indoktrinasi (TUBAPI) sebagai buku sumber, tahun 1962 istilah civics diganti dengan Kewargaan Negara, tahun 1968 Kewargaan Negara di ganti dengan Pendidikan Kewargaan Negara. Tahun 1975 Pendidikan Kewargaan Negara di ganti dengan PMP (Pendidikan Moral Pancasila), tahun 1978 sangat dominannya materi P-4 dalam PMP. Tahun 1984 masih dengan nama PMP, tahun 1994 di ganti dengan nama PPKn. Tahun 1999 materi P-4 dicabut. Era reformasi di rubah dengan Pendidikan Kewarganegaraan (PKn), yang kemudian pada tahun 2013 kembali lagi menjadi PPKn.

Perkembangan kurikulum PPKn di Indonesia berkembang secara dinamis ini pada prinsipnya disesuaikan dengan kebutuhan serta visi-misi dari pemerintah yang mempengaruhi dalam pembentukan kebijakan kurikulum pendidikan di Indonesia. Tetapi dalam pelaksanaannya terdapat kekuatan yang menjadi fondasi dalam pelaksanaan mata pelajaran Pendidikan Pancasila dan Kewarganegaraan, yaitu Pancasila, UndangUndang Dasar Negara Republik Indonesia Tahun 1945, politik, hukum, nilai, moral, kearifan 
lokal, dan kebhinekaan dalam berkebudayaan.

Begitu dinamisnya

perkembangan kurikulum khususnya di bidang PPKn, ini tidak lepas dari perkembangan situasi politik hukum negara Indonesia. Bahkan, Samsuri (2012) memaparkan bahwa "besarnya kepentingan rezim kekuasaan terhadap pendidikan kewarganegaraan model PMP tersebut, mengakibatkan terjadinya reduksionisme misi mata kajian itu dalam kerangka membentuk warga negara yang baik. Reduksi itu nampak Ketika pendidikan Pancasila yang dieksplisitkan dengan label PMP, seakan-akan menjadi satusatunya mata pelajaran yang harus bertanggung jawab terhadap pembentukan karakter warga negara, khususnya kepada generasi muda".

Bagi akademisi, khususnya di bidang PPKn, sudah sepatutnya kita peduli dan terus menganalisis bagaimana perkembangan bidang kajian PPKn baik secara normatif, maupun substantif.

\section{B. Saran}

Seperti yang telah peneliti jelaskan pada simpulan, bahwa sebagai akademisi bidang PPKn, sudah sepatutnya ada antusiasme dan respons yang cepat terkait dengan adanya perkembangan kurikulum PPKn. Oleh sebab itu, peneliti menyarankan kepada akademisi pada umumnya, dan akademisi bidang PPKn pada khususnya, untuk terus mengikuti perkembangan yang terjadi pada kurikulum di Indonesia. Seperti yang telah peneliti paparkan di artikel ini, perubahan kurikulum terjadi sangat dinamis dan cepat, hamper semua subjek mata pelajaran terkena dampak akan perubahan yang dinamis ini, termasuk bidang PPKn. Oleh sebab itu, akademisi bidang PPKn seharusnaya menjadi kaum yang paling awal untuk mengawal dan mengikuti proses perkembangan ini. 
81 Raharjo: analisis perkembangan kurikulum ppkn: dari rentjana pelajaran ...

\section{DAFTAR PUSTAKA}

\section{Buku, Jurnal, dan Peraturan Perundang-undangan:}

Alhamuddin. 2014. Sejarah Kurikulum Di Indonesia (Studi Analisis Kebijakan Pengembangan Kurikulum). Nur El-Islam, Volume 1, Nomor 2, Oktober 2014.

Aman, Sofyan, dkk. 1982. Pedoman Didaktik Metodik Pendidikan Moral Pancasila untuk para Guru SD, SLTP dan SLTA, Jakarta: PN Balai Pustaka.

Budimansyah, D. 2010. Penguatan pendidikan kewarganegaraan untuk membangun karakter bangsa. Bandung: Widya Aksara Press.

Danial A.R. Nanan. 2009. Metode Penulisan Karya Ilmiah. Bandung: Laboratorium PKn Universitas Pendidikan Indonesia.

Darmodiharjo, D. 1980. Orientasi Singkat Pancasilall Laboratorium Pancasila IKIP Malang. Santiaji Pancasila. Surabaya: Usaha Nasional.

Daulay, Haidar Putra. 2001. Historitasdan Eksistensi Pesantren Sekolah dan Madrasah. Yogyakarta: Tiara Wacana.

Hamalik, Oemar. 2004. Model-Model Pengembangan Kurikulum. Bandung: PPs Unversitas Pendidikan indonesia (UPI).

Kementerian Pendidikan dan Kebudayaan, Desain Induk Kurikulum 2013. Jakarta: Kemendikbud.

Kementerian Pendidikan dan Kebudayaan. 2013. Draft Kurikulum 2013. Jakarta: Kemendikbud.

Kepmendikbud No. 060/U/1993 tanggal 25 Februari 1993 Kurikulum Pendidikan Dasar, GBPP SD Mata Pelajaran PPKn

M. Asri. 2017. Dinamika Kurikukum di Indonesia, MODELING: Jurnal Program Studi PGMI Volume 4, Nomor 2, September 2017.

Machali, Imam \& Ara Hidayat. 2016. The Handbook of Education Management: Teori dan Praktik Pengelolaan Sekolah/Madrasah di Indonesia. Jakarta: Prenadamedia Group.

Mulyasa. 2013. Pengembangan dan Implementasi Kurikulum 2013. Bandung: PT.Remaja Rosdakarya.

Nahrawi, Amirudin. 2008. Pembaharuan Pendidikan Pesantren. Yogyakarta: Gama Media.

Permendikbud nomor 3 Tahun 2020 tentang Standar Nasional Pendidikan Tinggi

S. Nasution. 1995. Asas-asas Kurikulum. Jakarta: Bumi Aksara.

Samsuri. 2012. Kurikulum Pendidikan Pancasila dan Kewarganegaraan : Dari Politik Rezim ke Politik Negara untuk Membangun Warga Negara Ideal. Makalah disajikan di Seminar Nasional Menyongsong Kurikulum 
Nasional,\| Pengurus Pusat IKAPI, Aula Perpustakaan Nasional Jakarta, 29 Oktober 2012

Sanjaya, Wina. 2005. Pembelajaran dalam Implementasi Kurikulum Berbasis Kompetensi. Jakarta: Kencana Prenada Media Group.

Santoso, G., Al Muchtar, S., \& Abdulkarim, A. (2015). Analysis SWOT Civic Education curriculum for senior high school year 1975-2013. CIVICUS: JURNAL PENDIDIKAN KEWARGANEGARAAN, 19(1).

Schubert. 1986. Curriculum Prespective, Paradigm, and Posibility. New York. McMillan Publishing Company.

Somantri, M. N. (2001). Menggagas Pembaharuan Pendidikan IPS. Bandung: Rosda Karya.

Stratemeyer, Florence., B, Forkner,HL., McKim, GM. 1947. Developing a Curriculum for Modern Living. Columbia: Bureau of Publication, Teacher College.

Surakhmad, Winarno. 2009. Pendidikan Nasional Strategi dan Tragedi. Jakarta: PT. Kompas Media Nusantara.

Internet:

https://www.kemdikbud.go.id/main/blog/2020/05/reformasi-pendidikan-nasionalmelalui-merdeka-belajar) 